\title{
sciforum
}

\section{MOLECULAR DOCKING OF FRUCTOSE-DERIVED NUCLEOSIDE ANALOGS AGAINST REVERSE TRANSCRIPTASE OF HIV-1}

\author{
Alex France Messias Monteiro ${ }^{a}$, Marcus Tullius Scotti ${ }^{a}$, Luciana Scotti ${ }^{a, b}$ \\ ${ }^{a}$ Federal University of Paraíba, Laboratory of Pharmaceutical Technologies, 50670-910, João Pessoa, PB, Brazil. \\ ${ }^{b}$ Teaching and Research Management - University Hospital, Federal University of Paraíba, João Pessoa, PB, Brazil..
}

\begin{abstract}
AIDS is a chronic infection that compromises the immune system of the individual infected with HIV. $\mathrm{HIV}$ is a retrovirus, that is, it has RNA as a genetic material, and needs the action of reverse transcriptase (RT) to multiply. A nucleoside is formed by the bond between a carbohydrate and a nitrogenous base that is inserted into the genetic material preventing multiplication. This work consists of a computational analysis through Molecular Docking in order to predict the potential inhibitory activity of RT from a series of 24 nucleoside analogs derived from fructopyranose compared to the bioactive molecules already inserted in the anti-HIV treatment. For this study 36 molecules were designed in ChemDraw Ultra 12.0 to obtain its 2D structural formula. Then the molecule was optimized MM + and AM1 using HyperChemTM (Release 8.0.6 for Windows). Finally, the enzyme RT in PBD (PDB ID 1REV) was selected and in Molegro Virtual Docking 6.0 anchorage was performed. It is possible to conclude that some molecules presented favorable energies for the formation of the ligand-enzyme complexes, as well as the presence of interactions with amino acid residues common to known inhibitors.
\end{abstract}

Keywords: nucleosides, HIV, reverse transcriptase, molecular modeling, virtual screening, in silico.

\section{INTRODUCTION}

AIDS is still considered a pandemic, considered as a global public health problem that has contributed to the deaths of 35 million people infected, with 1 million deaths occurring in 2016 as victims of HIV-related immunodeficiency. According to the World Health Organization (WHO) survey in 2016 there were 36.7 million infected, of whom 1.8 million were infected in the same year of the survey. (WHO, 2018a; France, 2016) 
The demographic distribution WHO (2018a) of those infected by HIV shows that $69.83 \%$ of the cases are distributed on the African continent, followed by $9.55 \%$ in Southeast Asia and $9.00 \%$ in the American continent.

HIV is a virus of the family Retroviridae, a family of viruses whose genome is formed by a single strand of RNA and its parasitological life cycle begins by the synthesis of its DNA from its own viral RNA, through the enzyme reverse transcriptase (RT). Continuing the HIV taxonomy, it is within the lentivirus genre in which viruses with high incubation times are present, and the infected individual can spend long periods with the virus asymptomatically in the body. It is worth noting that lentiviruses have an ability to replicate, giving greater speed to the evolution to an infectious disease (Acquired Immunodeficiency Syndrome - AIDS). (Sanjuán \& Bordería, 2010; Mustanski, Newcomb, Du Bois, Garcia \& Grov, 2011; Jiang Et Al., 2010; Siqueira, 2012)

One of the therapeutic alternatives commonly used in retroviral treatment is the use of nucleoside analogues to inhibit the action of RT (France, 2016; Nunes, Caliani, Nunes \& Mello, 2015). Nucleoside analogs are not differentiable from the natural nucleosides by the enzyme, where these once incorporated analogs do not are recognized and prevents clustering in the natural nucleotides, thus, the entire viral multiplication process is terminated.

According to several studies, retroviral anti-HIV treatment can be classified into 3 distinct pharmacological forms of action with their chronological order in the treatment history of those infected: in 1991 the nucleoside RT inhibitors, 1995 the protease inhibitors and in 1996 the nonnucleoside inhibitors of RT (Nunes, Caliani, Nunes \& Mello, 2015; Novotny, Hendrickson, Soares, Sereno, \& Kiene, 2017; Bittencourt et al., 2015). The Food and Drug Administration (FDA) also adds integrase inhibitors, fusion inhibitors and CCR5 inhibitors (Lozano et al., 2012). Thus, after insertion of these drugs, it was possible to perceive the decrease in the mortality of HIV-infected individuals.

One of the strategies used today in modern medical chemistry is the insertion of computational methods for the planning of new drugs (Veljkovic, 2006; Guido, Andricopulo \& Oliva, 2010; Lima, 207). Through in silico methods it is possible to perform a screening by analyzing some important aspects for the promotion of a drug bioactive, such as anchoring with the target (molecule-receptor system), toxicity and metabolism of the substance, thereby selecting molecules with better profile with promising pharmacodynamic and pharmacokinetic properties. (Jónsdóttir, Jorgensen \& Brunak, 2005; 15; Miller et al., 2017; Andricopulo \& Montanari, 2005)

Zidovudine (AZT), Figure 01, was the first drug synthesized in 1964 to be used in anti-HIV treatment (Fischl et al., 1987), this substance has the function of inhibiting the action of the enzyme that performs viral DNA synthesis when the virus parasite the cell. This drug reduces up to $80 \%$ the presence of opportunistic diseases in seropositive patients and up to $50 \%$ the deaths caused by secondary diseases. (France, 2016; Nunes et al., 2015; Fischl et al., 1987; Horwitz, Chua \& Noel, 1964) 


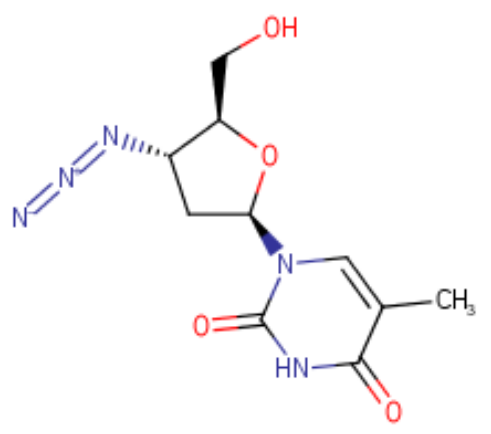

Figure 01. Structure 2D of zidovudine (AZT).

For this study, in silico studies were performed through the Molecular Docking to know the energy of interaction with the specific receptor, involving the inhibition of RT. With this screening, it is possible to select molecules with anti-HIV profile, derived from the fructospermine, taking as a positive control the molecule of AZT. These data may be used to propose nucleoside analogs from those identified in this screening with improved biological activity.<smiles>C[C@H]1CCO[C@H]2Cn3cc(C(=O)NCc4ccc(F)cc4F)c(=O)c(O)c3C(=O)N12</smiles>

Figure 02. Structure Dolutegravir (DTG) 2D.

The importance of studies in this area is due to the great toxicity that bioactive molecules with anti-HIV profile present against normal cells, especially hepatic, neural and gastric cells, considering that the bioactive drugs used in the treatment of AIDS also have activity against non-specific enzymes such as protease and integrase, both enzymes present in healthy cells. Recently the WHO published an alert about the risks that the use of dolutegravir - DTG (Figure 02) at conception can offer to the neural tube of the fetus. (WHO, 2018b)

A nucleoside is formed by the union of a carbohydrate and a nitrogenous base, commonly using pentoses and deoxypentoses, in which the $N$-glycosidic covalent bond is formed commonly between $N^{9}{ }_{\text {base- }} C^{1}$ carbohydrate in the purine bases and $N^{1}$ base- $C^{1}$ carbohydrate in the pyrimidine bases . (France, 2016; Champe, Harvey \& Ferrier, 2011; Nelson, 2002)
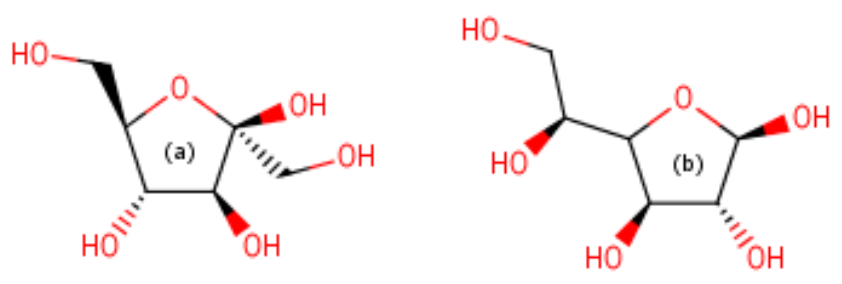
Figure 03. Structure 2D of $\beta$-fructofuranose (a) and $\beta$-glucofuranose (b)

The fructose (Figure 03a) is a monosaccharide very abundant in the human body (Barreiros, Bossolan \& Trindade, 2005), which is also present in fruits, its consumption is recommended to patients with a high glycemic rate, in the control of diabetes, since it has a chemical structure similar to glucose (Figure 03b) and a very pronounced sweet taste (Oliveira \& Marchini, 2008), however the great difference between these two carbohydrates lies in their distinct metabolisms, since glucose requires insulin.

\section{MATERIAL OF METHOD}

In this work a virtual screening of 24 nucleosides (Table 01 ) derived from $\beta$-fructofuranose with different nitrogenous, purine and pyrimidine bases was performed, together with 12 molecules of drugs already used in anti-HIV treatment, to identify the best profile of the studied series. And the interactions between amino acid residues common to better profile molecules.

Initially all these molecules had their structures optimized by two methods, then the Molecular Docking was performed using a protein from the PDB (Protein Data Bank - https://www.rcsb.org), referring to the TR, after the anchorage to best pose for each molecule was chosen according to the corresponding MolDock Score values.

Table 01. Compounds used in the research.

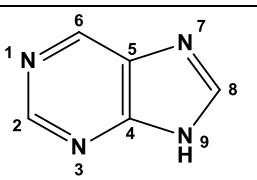

Purines

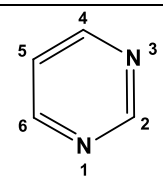

Pirimidines

\begin{tabular}{l|c|c|c|c|c}
\hline Cod. & Compound & PM & Cód. & Compound & PM \\
\hline ALX01 & Abacavir & 300.359 & ALX19 & Indinavir & 613.789 \\
\hline ALX02 & Adefovir & 273.186 & ALX20 & $N^{3}$-(orotine acid)-R & 318.237 \\
\hline ALX03 & $N^{9}$-adenine-R & 297.267 & ALX21 & $N^{1}, N^{3}$-(orotine acid)-di-R & 480.377 \\
\hline ALX04 & AZT & 267.241 & ALX22 & $N^{1}$-(orotine acid)-R & 318.237 \\
\hline ALX05 & $N^{1}$-barbiturine-R & 290.227 & ALX23 & $N^{3}$-paraxantine-R & 342.305 \\
\hline ALX06 & $N^{1}, N^{3}$-barbiturine-di-R & 452.367 & ALX24 & Telbuvudina & 242.229 \\
\hline ALX07 & Cidofovir & 279.187 & ALX25 & Tenofovir & 287.212 \\
\hline ALX08 & $N^{1}$-citosine-R & 273.243 & ALX26 & $N^{1}$-teobromina-R & 342.305 \\
\hline ALX09 & Didanosina & 236.227 & ALX27 & $N^{9}$-teofiline-R & 342.305 \\
\hline ALX10 & Efavirez & 315.675 & ALX28 & $N^{1}$-timine-R & 288.254 \\
\hline ALX11 & Emtricitabina & 247.247 & ALX29 & $N^{1}$-uracine-R & 274.227 \\
\hline ALX12 & Entecavir & 277.279 & ALX30 & $N^{9}$-(urine acid)-R & 330.251 \\
\hline ALX13 & Estavudina & 224.213 & ALX31 & $N^{7}$-(urine acid)-R & 330.251 \\
\hline ALX14 & Fructose & 292.218 & ALX32 & $N^{1}$-(urine acid)-R & 330.251 \\
\hline ALX15 & $N^{1}$-(F-uracine)-R & 180.156 & ALX33 & $N^{3}$-(urine acid)-R & 330.251 \\
\hline
\end{tabular}


http://sciforum.net/conference/mol2net-05

\begin{tabular}{c|c|c|c|c|c|c}
\hline ALX16 & $N^{9}$-guanine-R & 313.267 & ALX34 & $N^{9}$-xantine-R & 314.251 \\
\hline ALX17 & $N^{9}$-hipoxantine-R & 298.252 & ALX35 & $N^{3}$-xantine-R & 314.251 \\
\hline ALX18 & $N^{1}$-hipoxantine-R & 298.252 & ALX36 & $N^{1}$-xantine-R & 314.251 \\
\hline
\end{tabular}

Molecular Weight $-[\mathrm{PM}]=$ g.mol-1

$\beta$-fructofuranoside- $\mathrm{R}$

For better discussion it is convenient to calculate two pharmacodynamic and pharmacokinetic parameters as the absorption rate (\% ABS) (Silva et al., 2015; Oliveira et al., 2012; Peixoto et al., 2016) and the inhibitory constant $\left(\mathrm{K}_{\mathrm{i}}\right)$, through the following equations:

$$
\begin{array}{cc}
\% \mathrm{ABS}=109-(0.3345 \times \mathrm{TPSA}) & \text { Equation } 01 \\
\Delta \mathrm{G}=-\mathrm{RT} \ln \mathrm{K}_{\mathrm{i}} & \text { Equation } 02
\end{array}
$$

Thus, the prediction of these two parameters may contribute to the selection of the molecules with better prototypical biological profiles to drugs, for this it is necessary to predict the Polar Topological Surface Area (TPSA) (Ertl, Rohde \& Selzer, 2000; Fernandes \& Gattass, 2009; Schaftenaar \& Vlieg, 2012; Jarrahpour et al., 2012; Jarrahpour et al., 2010; Lahsasni et al., 2014; Hou, Zhang, Xia, Qiao \& Xu, 2004), in this research this prediction was performed through of the free Molinspiration ${ }^{\circledR}$ online application (Bratislava University, 2017). The inhibition constant was calculated from the anchoring energies obtained in the molecular docking, where $\mathrm{R}$ is the general constant of the perfect gases and $\mathrm{T}$ is the temperature.

\section{Molecular Docking}

Initially the molecules were designed in their 2D form in the ChemDraw Ultra 12.0 program (Berić, Jelić, Nešić, Trbojević-Stanković \& Odović, 2017), for the anchorage study (ligand-receptor) initially all the molecules had their energy minimized in the search of the lower energy conformation (RMS $0.1 \mathrm{Kcal} / \AA$ (MM +) (Allinger, 1977). The algorithm was developed using the HyperChemTM (Release 8.0.6 for Windows) software, using the force field of molecular mechanics $(\mathrm{MM}+)$ (Allinger, 1977) and the semi-empirical (AM1) (Dewar, Zoebisch, Healy \& Stewart, 1985). The target chosen for this research was the PDB ID (Berman et al., 2000) 1REV (Ren et al., 1995), because it corresponds to an enzyme protein to be inhibited, once chosen, the target was imported into the software Molegro Virtual Docking 6.0 (MVD) to realize the template selecting the appropriate interaction site, after all, molecular anchoring was started.

\section{Qualitative prediction of toxicity}

In addition to the anchoring with the chosen receptor, a qualitative in silico study was performed to predict the toxicity of each compound, making it a parameter of selection of structures with good anti-HIV pharmacological profiles. Knowing that these compounds have affinity for other 
active sites in several targets already mentioned, the toxicity becomes a fundamental parameter for the election of a bioactive to drug. For this study we used the free Vega QSAR software (see 1.1.3 build date: 19/09/2016) (Ghorbanzadeh, Zhang \& Andersson Patrik, 2016; Benfenati, Manganaro \& Gini, 2013; Golbamaki et al., 2014; Pizzo, Lombardo, Manganaro \& Benfenati, 2013) developed in the Java ${ }^{\circledR}$ for Windows programming language.

\section{RESULTS AND DISCUSSION}

\section{Molecular Docking}

According to the energetic data obtained in the molecular docking (Souza, 2012; Simonetti et al., 2017; Almeida, 2018; Oliveira et al., 2008; Cardoso, Moraes \& Cass, 2009; Soares, 2011; Foresto et al., 2017) (Table 02) correlating with the structures of 12 drugs used in the treatment of seropositive, among the structures of the nucleoside analogues studied, only two had low affinity for the binding site (ALX05 and ALX015).

Table 02. Values obtained after molecular anchoring.

\begin{tabular}{c|c|c|c|}
\hline Cod. & MolDock Score & Cod. & MolDock Score \\
\hline ALX01 & -117.9960 & ALX19 & -178.2620 \\
\hline ALX02 & -97.7808 & ALX20 & -91.9244 \\
\hline ALX03 & -98.2466 & ALX21 & -103.0860 \\
\hline ALX04 & -96.1751 & ALX22 & -85.0810 \\
\hline ALX05 & -61.9241 & ALX23 & -81.4854 \\
\hline ALX06 & -100.4870 & ALX24 & -84.5389 \\
\hline ALX07 & -93.1448 & ALX25 & -101.9030 \\
\hline ALX08 & -80.2223 & ALX26 & -76.8097 \\
\hline ALX09 & -85.5961 & ALX27 & -92.1091 \\
\hline ALX10 & -104.8640 & ALX28 & -81.8189 \\
\hline ALX11 & -75.6019 & ALX29 & -85.0627 \\
\hline ALX12 & -103.0430 & ALX30 & -105.8900 \\
\hline ALX13 & -71.6477 & ALX31 & -102.3530 \\
\hline ALX14 & -88.6736 & ALX32 & -93.9533 \\
\hline ALX15 & -51.2576 & ALX33 & -88.9166 \\
\hline ALX16 & -104.0450 & ALX34 & -100.7800 \\
\hline ALX17 & -94.9336 & ALX35 & -83.2611 \\
\hline ALX18 & -77.3818 & ALX36 & -76.9175 \\
\hline
\end{tabular}

The analysis of the MolDock Score reveals that 22 nucleoside analogs studied presented better results than the drugs Emtricitabine and Stavudine, that 15 compounds had better results than Telbivudine, 13 were better than Didanosine and that 1 compound had a better result than 10 (out of 12 ) bioactive drugs present in anti-HIV drugs, as shown in the bar chart in Figure 04: 


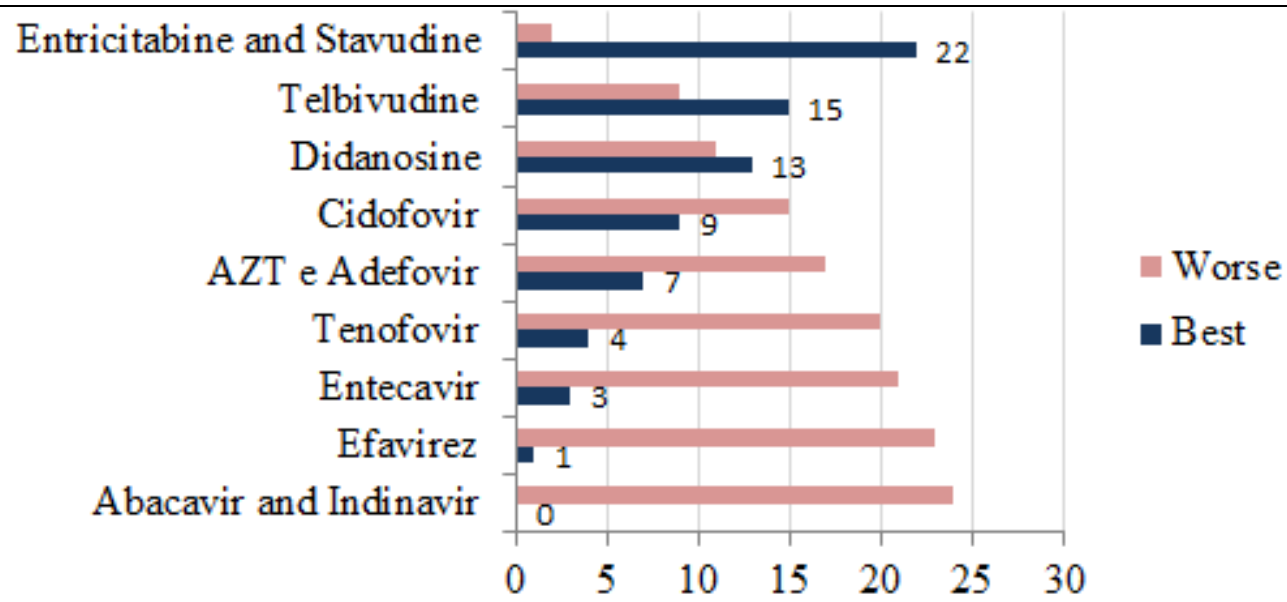

Figure 04. Relationship between analogs and selected drugs.

The analogue that showed the best interaction with the chosen target was the compound with code ALX30, which corresponds to a fructofuranose bound by anomeric carbon with the $N^{9}$ atom of uric acid, through a $\beta$ - $N$-glycosidic bond (Figure 05).<smiles>O=c1[nH]c(=O)c2[nH]c(=O)n([C@]3(CO)O[C@H](CO)[C@@H](O)[C@H]3O)c2[nH]1</smiles>

Figure 05. Structure 2D of compound ALX30.

Among the analogues studied in this research, it is relevant to highlight the molecules ALX16, ALX21, ALX30 and ALX31, as they presented better anchorage results than Tenofovir, a drug used in the 3 in 1 treatment adopted in Brazil, which consists in the administration of 1 tablet containing Tenofovir + Lamivudine + Efavirez (Foresto et al., 2017; Santos, Secoli \& Padoin, 2016; Barros \& Vieira-da-Silva, 2017; Silva, Dourado, Brito \& Silva, 2015). AZT is a drug approved since 1987 by the FDA (Fischl, 1987) used in the treatment of HIV-positive seropositive patients and since 1990 has been incorporated into the Pre-Exposure Prophylaxis (PRPE) preventive treatment, according to data obtained from molecular docking in this ALX06, ALX16, ALX21, ALX30, ALX31 and ALX34 showed promising MolDock Score results for the inhibition of RT (Figure 06).

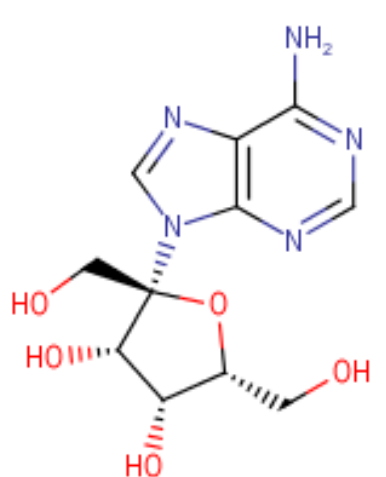

ALX03

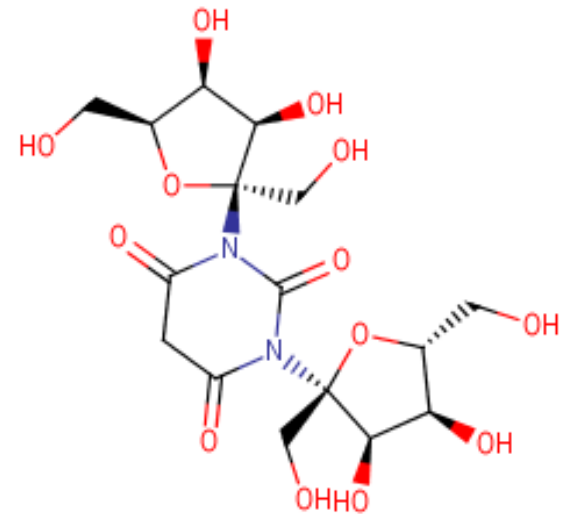

ALX06 


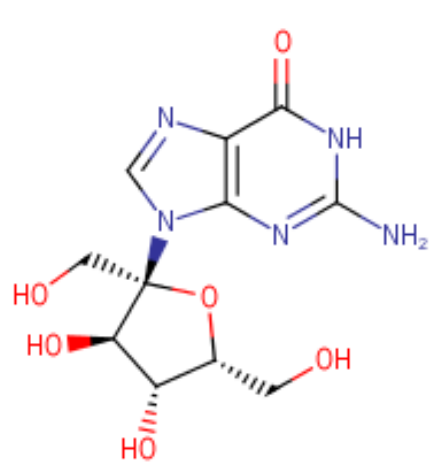

ALX16<smiles>O=c1[nH]c(=O)c2[nH]c(=O)n([C@]3(CO)O[C@H](CO)[C@@H](O)[C@H]3O)c2[nH]1</smiles>

ALX30<smiles>O=C(O)c1cc(=O)n([C@]2(CO)O[C@H](CO)[C@@H](O)[C@H]2O)c(=O)n1[C@]1(CO)O[C@H](CO)[C@@H](O)[C@H]1O</smiles>

ALX21<smiles>O=c1[nH]c(=O)c2c([nH]1)[nH]c(=O)n2[C@@]1(CO)O[C@H](CO)[C@@H](O)[C@H]1O</smiles>

ALX31<smiles>O=c1[nH]c(=O)c2ncn([C@]3(CO)O[C@H](CO)[C@@H](O)[C@H]3O)c2[nH]1</smiles>

ALX34

Figure 06. Molecules with better anchoring energies than AZT.

\section{Absorption Rate and Inhibitory Constant}

For the investigational study of the potentiality of a compound as a drug candidate it is necessary to discuss the rate of absorption of the bioactive (\% ABS), TPSA data were essential for the prediction of\% ABS (Costa et al., 2016; Singh, Sharma, Mishra, Pandiya \& Kumar, 2017; Singh, Gupta \& Verma, 2013; Singh \& Singh, 2011), 22 The compounds of the present invention have a value of between 40\% and 100\%: ALX03, ALX08, ALX14, ALX14, ALX15, ALX16, ALX17, ALX18, ALX20, ALX22, ALX22, ALX23, ALX26, ALX28, ALX28, ALX29, ALX30, ALX31, ALX35 and ALX36, as shown in the bar graph in Figure 07: 


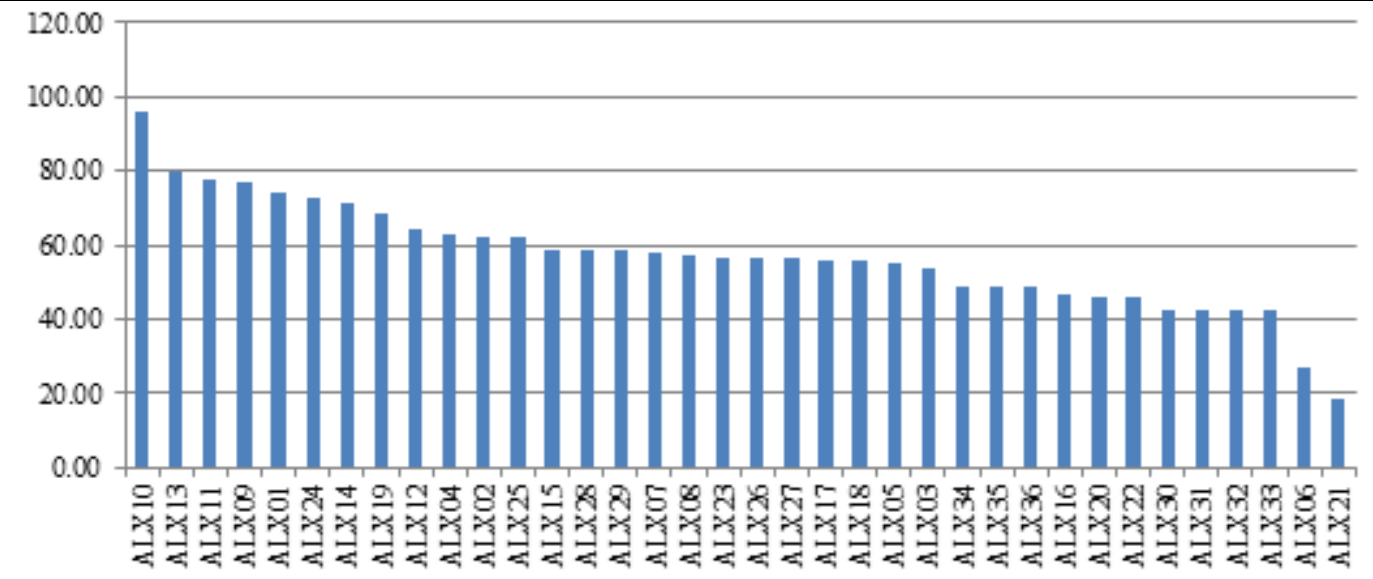

Figure 07. Relationship of compounds based on\% ABS.

Comparing the relation of the compounds classified by the absorption rate with the compounds that presented the best results in molecular docking, it is possible to highlight five compounds that presented satisfactory results in both chemoinformatic analyzes: ALX03, ALX16, ALX30, ALX31 and ALX34.

Another important parameter besides the absorption rate is the inhibitory constant $\left(\mathrm{K}_{\mathrm{i}}\right)$, with which it is possible to classify the compounds as to the degree of receptor-ligand affinity, according to the data presented in Table 04 concerning the predictions of some properties relevant for In this study (Equation 02), we can see the $\mathrm{K}_{\mathrm{i}}$ values that the compound ALX03 presented better interactions among the 5 compounds selected by the two previous analyzes (Table 03).

Table 03. Prediction values of some properties.

\begin{tabular}{|c|c|c|c|c|c|c}
\hline Cod. & $\mathrm{K}_{\mathrm{i}}$ & miLogP & HBA & HBD & TPSA & $\%$ ABS \\
\hline ALX01 & 1.0488 & 1.47 & 07 & 04 & 101.89 & 73.85 \\
\hline ALX02 & 1.0402 & -0.98 & 09 & 04 & 136.39 & 61.95 \\
\hline ALX03 & 1.0404 & -1.42 & 10 & 06 & 159.78 & 53.88 \\
\hline ALX04 & 1.0396 & -0.10 & 09 & 02 & 134.08 & 62.74 \\
\hline ALX05 & 1.0253 & -2.40 & 10 & 05 & 156.62 & 54.97 \\
\hline ALX06 & 1.0414 & -4.35 & 15 & 08 & 237.98 & 26.90 \\
\hline ALX07 & 1.0383 & -2.70 & 09 & 05 & 147.91 & 57.97 \\
\hline ALX08 & 1.0329 & -2.49 & 09 & 06 & 151.07 & 56.88 \\
\hline ALX09 & 1.0351 & -0.95 & 07 & 02 & 93.04 & 76.90 \\
\hline ALX10 & 1.0432 & 4.53 & 03 & 01 & 38.33 & 95.78 \\
\hline ALX11 & 1.0310 & -0.67 & 06 & 03 & 90.38 & 77.82 \\
\hline ALX12 & 1.0424 & -1.06 & 08 & 05 & 130.06 & 64.13 \\
\hline ALX13 & 1.0293 & -0.54 & 06 & 02 & 84.33 & 79.91 \\
\hline ALX14 & 1.0209 & -2.04 & 06 & 05 & 110.37 & 70.92 \\
\hline ALX15 & 1.0364 & -2.24 & 09 & 05 & 145.01 & 58.97 \\
\hline ALX16 & 1.0429 & -2.58 & 11 & 07 & 179.75 & 46.99 \\
\hline ALX17 & 1.0390 & -2.38 & 10 & 05 & 153.73 & 55.96 \\
\hline ALX18 & 1.0317 & -1.44 & 10 & 05 & 153.73 & 55.96 \\
\hline ALX19 & 1.0746 & 2.51 & 09 & 04 & 118.02 & 68.28 \\
\hline ALX20 & 1.0378 & -2.52 & 11 & 06 & 182.31 & 46.10 \\
\hline
\end{tabular}




\begin{tabular}{l|l|l|l|l|l|l}
\hline ALX21 & 1.0425 & -4.16 & 16 & 09 & 261.60 & 18.75 \\
\hline ALX22 & 1.0349 & -2.52 & 11 & 06 & 182.31 & 46.10 \\
\hline ALX23 & 1.0334 & -1.66 & 11 & 04 & 151.98 & 56.57 \\
\hline ALX24 & 1.0347 & -1.43 & 07 & 03 & 104.56 & 72.93 \\
\hline ALX25 & 1.0420 & -0.62 & 09 & 04 & 136.39 & 61.95 \\
\hline ALX26 & 1.0315 & -1.66 & 11 & 04 & 151.98 & 56.57 \\
\hline ALX27 & 1.0379 & -1.66 & 11 & 04 & 151.98 & 56.57 \\
\hline ALX28 & 1.0336 & -1.95 & 09 & 05 & 145.01 & 58.97 \\
\hline ALX29 & 1.0349 & -2.65 & 09 & 05 & 145.01 & 58.97 \\
\hline ALX30 & 1.0436 & -3.09 & 12 & 07 & 193.67 & 42.18 \\
\hline ALX31 & 1.0422 & -3.09 & 12 & 07 & 193.67 & 42.18 \\
\hline ALX32 & 1.0386 & -2.15 & 12 & 07 & 193.67 & 42.18 \\
\hline ALX33 & 1.0365 & -3.09 & 12 & 07 & 193.67 & 42.18 \\
\hline ALX34 & 1.0415 & -2.74 & 11 & 06 & 173.70 & 49.07 \\
\hline ALX35 & 1.0342 & -2.74 & 11 & 06 & 173.70 & 49.07 \\
\hline ALX36 & 1.0315 & -1.79 & 11 & 06 & 173.70 & 49.07 \\
\hline
\end{tabular}

HBA - Hydrogen Binding Acceptors; HBD - Hydrogen Binding Donors; Log P -

Partition Coefficient (Octanol / Water); Ki - Inhibitory Constant.

\section{Qualitative prediction of toxicity}

A qualitative toxicity prediction was made in order to further restrict the relationship of promising structures to anti-HIV drugs, initially in this study the nature of the toxicity and its toxic action mechanism were not considered, only to know their relative toxicity (Price \& Chaudhry, 2014; Benfenati, Manganaro \& Gini, 2013; Mombelli, Raitano \& Benfenati, 2016; Veljkovic et al., 2015). Desiring the Boolean results obtained, the compounds ALX03 and ALX16 presented toxicity, but the compounds ALX30, ALX31 and ALX34 do not present any apparent relative toxicity according to the software used for this in silico screening. All results for each sample can be seen in Frame 01 along with the reliability of each prediction.

Frame 01. Qualitative analysis on general toxicity.

\begin{tabular}{c|c|c|c|c|c}
\hline Cod. & Reab. & Toxidade & Cod. & Reab. & Toxidade \\
\hline ALX01 & Low & Yes & ALX19 & Low & No \\
\hline ALX02 & Low & Yes & ALX20 & Low & No \\
\hline ALX03 & Low & Yes & ALX21 & Low & No \\
\hline ALX04 & Low & Yes & ALX22 & Low & No \\
\hline ALX05 & Low & No & ALX23 & Low & No \\
\hline ALX06 & Low & No & ALX24 & Moderate & No \\
\hline ALX07 & Low & Yes & ALX25 & Low & Yes \\
\hline ALX08 & Low & Yes & ALX26 & Low & No \\
\hline ALX09 & Low & Yes & ALX27 & Low & Yes \\
\hline
\end{tabular}




\begin{tabular}{l|c|c|c|c|c} 
ALX10 & Low & No & ALX28 & Low & Yes \\
\hline ALX11 & Low & Yes & ALX29 & Low & Yes \\
\hline ALX12 & Low & No & ALX30 & Low & No \\
\hline ALX13 & Good & Yes & ALX31 & Low & No \\
\hline ALX14 & Moderate & No & ALX32 & Low & No \\
\hline ALX15 & Low & No & ALX33 & Low & No \\
\hline ALX16 & Low & Yes & ALX34 & Low & No \\
\hline ALX17 & Low & Yes & ALX35 & Low & Yes \\
\hline ALX18 & Low & Yes & ALX36 & Low & Yes \\
\hline
\end{tabular}

Reab - Reability.

\section{Analysis of amino acid residues on the linker-receptor interaction}

This discussion brings about the existence of common interactions, all compounds showed interactions with similar residues, both the drugs and the nucleoside analogs studied: GLY190, LEU234, PHE227, PRO227, PRO236, TRY181, TYR188, VAL106, VAL179.

Residues TYR188, HIS235 and LYS101 were interacting with compounds ALX30, ALX31 and ALX34 through hydrogen bonds. In addition, the compounds showed a common amino acid residue with 9 of the drugs studied: TYR188, leading to the belief that these residues may influence the biological action of these compounds.

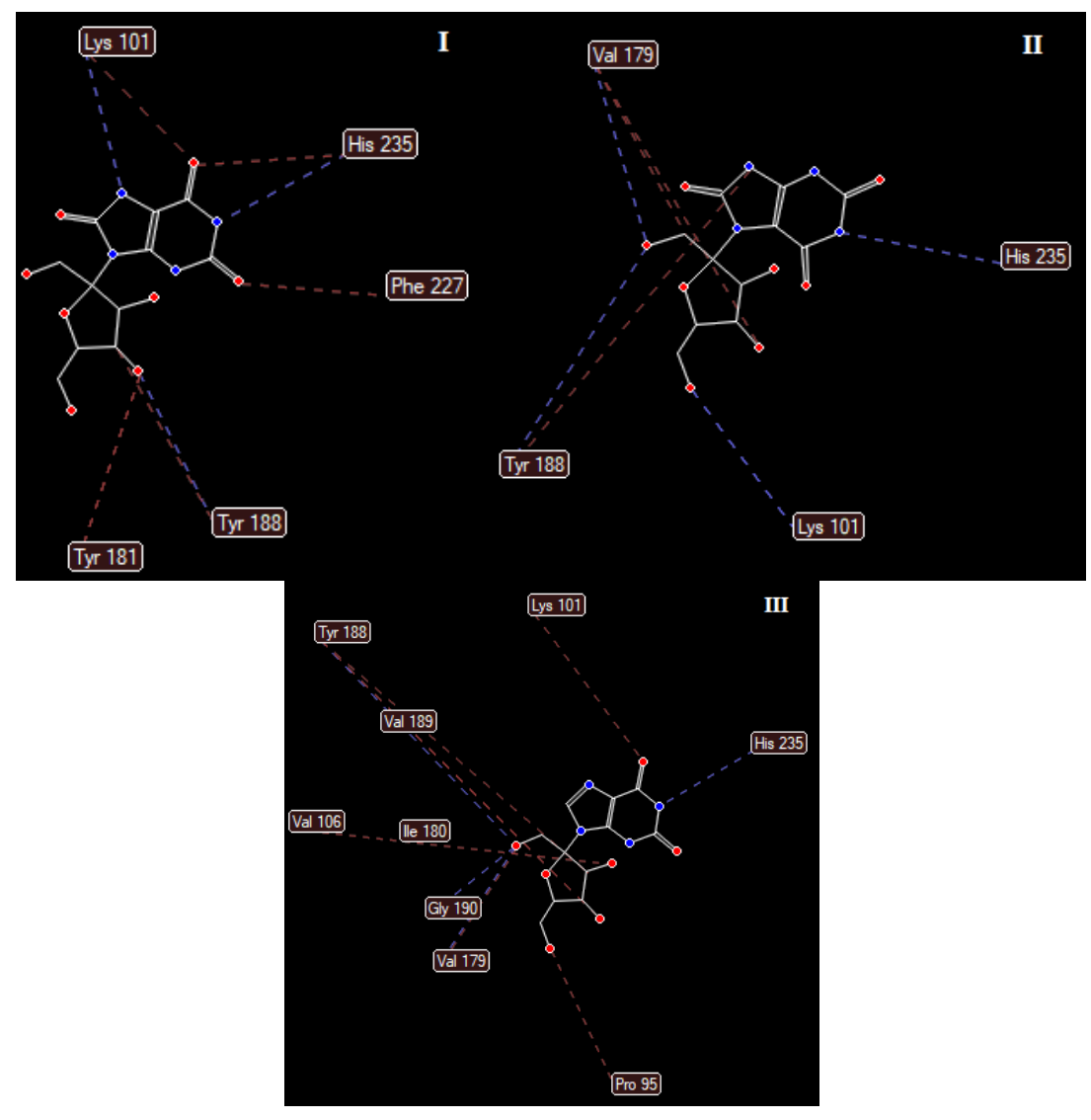

Figure 06. Interaction of ALX30 (I), ALX31 (II) and ALX34 (III) with the amino acid 
residues of the 1 REV target.

The compounds ALX30, ALX31 and ALX34 show interactions in 3 residues common among them and with the drugs selected in this research, as can be shown in Figure 06 where the blue dashed lines correspond to the hydrogen bonds and the red ones are steric interactions.

\section{CONCLUSION}

It may be concluded from the present work that fructose-derived nucleoside analogs may be bioactive anti-HIV promising, based on the data shown the compound which presented the best profile among the series worked in this study was compound ALX030, due to lower anchorage energy among the 3 compounds selected by screening (ALX30, ALX31 and ALX34), a compound formed by coupling between fructofuranosis and uric acid, an unpublished analog whose IUPAC name is 9 - [(2S, 3R, 4R, 5R) -3,4-dihydroxy-2,5-bis (hydroxymethyl)oxolan-2-yl]-2,3,6,7,8,9-hexahydro-1H-purine2,6,8-trione and a molecular weight of 330,251 g.mol-1. However, the compounds ALX31 and ALX34 also presented primitive results.

With the prediction of some pharmacodynamic and pharmacokinetic properties as the inhibition constant and the rate of absorption as well as the qualitative toxicity it was possible to restrict the series to only one compound, which presented the 10th lower energy in the molecular docking, showed no toxicity .

The hydrogen bonds and steric interaction of compounds ALX30, ALX31 and ALX34 were present in the drugs used as reference, presenting greater similarity with Didanosine, Entecavir, Efavirez, Tenofovir, Emtricitabina and Indinavir. Important interactions could be the biological activity of the molecule that presented better profile in this screening.

\section{ACKNOWLEDGEMENTS}

The authors thank the CNPq and Capes for financial support.

\section{REFERENCES}

Andricopulo, A. D., \& Montanari, C. A. (2005). Structure-activity relationships for the design of small-molecule inhibitors. Mini reviews in medicinal chemistry, 5(6), 585-593. doi:http://dx.doi.org/10.2174/1389557054023224

Allinger, N. L. (1977). Conformational analysis. 130. MM2. A hydrocarbon force field utilizing V1 and V2 torsional terms. Journal of the American Chemical Society, 99(25), 8127-8134. doi:10.1021/ja00467a001 
Almeida, B. C. D. (2018). Metabólitos secundários como potenciais inibidores de CDK8 (proteína quinase humana). Doctoral dissertation, Universidade de São Paulo, Brazil.

Barreiros, R. C., Bossolan, G., \& Trindade, C. E. P. (2005). Frutose em humanos: efeitos metabólicos, utilização clínica e erros inatos associados. Revista de Nutrição, 18, 377-389.

Barros, S. G. d., \& Vieira-da-Silva, L. M. (2017). A terapia antirretroviral combinada, a política de controle da Aids e as transformações do Espaço Aids no Brasil dos anos 1990. Saúde em Debate, 41, 114-128.

Benfenati, E., Manganaro, A., \& Gini, G. C. (2013). VEGA-QSAR: ai inside a platform for predictive toxicology.

Berić, J. D., Jelić, R. M., Nešić, D. M., Trbojević-Stanković, J. B., \& Odović, J. V. (2017). Estimation of plasma protein binding of selected antipsychotics using computed molecular properties. Archives of Biological Sciences, 69(3), 463-468.

Berman, H. M., Westbrook, J., Feng, Z., Gilliland, G., Bhat, T. N., Weissig, H., ...Bourne, P. E. (2000). The Protein Data Bank. Nucleic Acids Research, 28(1), 235-242. doi:10.1093/nar/28.1.235

Bittencourt, G. K. G. D., Moreira, M. A. S. P., Meira, L. C. d. S., Nóbrega, M. M. L. d., Nogueira, J. A., \& Silva, A. O. (2015). Concepções de idosos sobre vulnerabilidade ao HIV/Aids para construção de diagnósticos de enfermagem. Revista Brasileira de Enfermagem, 68, 579-585.

Bratislava University. (2017). Molinspiration Cheminformatics: calculation of molecular properties and bioactivity score. Retrieved May 15, 2018, from http://www.molinspiration.com/cgi-bin/properties

Cardoso, C. L., Moraes, M. C. d., \& Cass, Q. B. (2009). Imobilização de enzimas em suportes cromatográficos: uma ferramenta na busca por substâncias bioativas. Química Nova, 32, 175-187.

Champe, P. C., Harvey, R. A., \& Ferrier, D. R. (2011). Bioquímica Ilustrada (Ed. 5 ed.): Artmed Editora.

Costa, D. L., Silva, D. J., Fonseca, M. S., Arranja, T. C., Urbano, M. A., \& Sobral, J. A. (2016). Photophysical characterization and in vitro phototoxicity evaluation of 5,10,15,20-Tetra(quinolin-2yl)porphyrin as a potential sensitizer for photodynamic therapy. Molecules, 21(4). doi:10.3390/molecules21040439

Dewar, M. J. S., Zoebisch, E. G., Healy, E. F., \& Stewart, J. J. P. (1985). Development and use of quantum mechanical molecular models. 76. AM1: a new general purpose quantum mechanical molecular model. Journal of the American Chemical Society, 107(13), 3902-3909. doi:10.1021/ja00299a024 
Ertl, P., Rohde, B., \& Selzer, P. (2000). Fast calculation of molecular polar surface area as a sum of fragment-based contributions and its application to the prediction of drug transport properties. Journal of Medicinal Chemistry, 43(20), 3714-3717. doi:10.1021/jm000942e

Fernandes, J., \& Gattass, C. R. (2009). Topological polar surface area defines substrate transport by multidrug resistance associated protein 1 (MRP1/ABCC1). Journal of Medicinal Chemistry, 52(4), 1214-1218. doi:10.1021/jm801389m

Fischl, M. A., Richman, D. D., Grieco, M. H., Gottlieb, M. S., Volberding, P. A., Laskin, O. L., . . King, D. (1987). the efficacy of azidothymidine (AZT) in the treatment of patients with AIDS and AIDS-related complex. New England Journal of Medicine, 317(4), 185-191. doi:10.1056/NEJM198707233170401

Foresto, J. S., Melo, E. S., Costa, C. R. B., Antonini, M., Gir, E., \& Reis, R. K. (2017). Adesão à terapêutica antirretroviral de pessoas vivendo com HIV/aids em um município do interior paulista. Revista Gaúcha de Enfermagem, 38.

France, A. M. M. (2016). Síntese de novos análogos de nucleosídeos para utilização como fármaco contra HIV e VHB. Unpublished doctoral dissertation, Universidade Federal Rural de Pernambuco, Brazil).

Ghorbanzadeh, M., Zhang, J., \& Andersson Patrik, L. (2016). Binary classification model to predict developmental toxicity of industrial chemicals in zebrafish. Journal of Chemometrics, 30(6), 298-307. doi:10.1002/cem.2791

Golbamaki, A., Cassano, A., Lombardo, A., Moggio, Y., Colafranceschi, M., \& Benfenati, E. (2014). comparison of in silico models for prediction of daphnia magna acute toxicity. SAR and QSAR in Environmental Research, 25(8), 673-694. doi:10.1080/1062936X.2014.923041

Guido, R. V. C., Andricopulo, A. D., \& Oliva, G. (2010). Planejamento de fármacos, biotecnologia e química medicinal: aplicações em doenças infecciosas. Estudos Avançados, 24, 81-98.

Horwitz, J. P., Chua, J., \& Noel, M. (1964). Nucleosides. V. The Monomesylates of 1-(2'-Deoxy- $\beta$-Dlyxofuranosyl)thymine1,2. The Journal of Organic Chemistry, 29(7), 2076-2078. doi:10.1021/jo01030a546

Hou, T. J., Zhang, W., Xia, K., Qiao, X. B., \& Xu, X. J. (2004). ADME Evaluation in Drug Discovery. 5. Correlation of Caco-2 permeation with simple molecular properties. Journal of Chemical Information and Computer Sciences, 44(5), 1585-1600. doi:10.1021/ci049884m

Jarrahpour, A., Fathi, J., Mimouni, M., Hadda, T. B., Sheikh, J., Chohan, Z., ... Parvez, A. (2012). Petra, Osiris and Molinspiration (POM) together as a successful support in drug design: antibacterial activity and biopharmaceutical characterization of some azo Schiff bases. Medicinal Chemistry 
Research, 21(8), 1984-1990. doi:10.1007/s00044-011-9723-0

Jarrahpour, A., Motamedifar, M., Zarei, M., Youssoufi, M. H., Mimouni, M., Chohan, Z. H., ... Hadda, T. B. (2010). Petra, Osiris, and Molinspiration Together as a Guide in Drug Design: Predictions and Correlation Structure/Antibacterial Activity Relationships of New N-Sulfonyl Monocyclic $\beta$-Lactams. Phosphorus, Sulfur, and Silicon and the Related Elements, 185(2), 491-497. doi:10.1080/10426500902953953

Jiang, Y., B Ng, T., R Wang, C., Zhang, D., H Cheng, Z., K Liu, Z., ... Liu, F. (2010). Inhibitors from natural products to HIV-1 reverse transcriptase, protease and integrase. Mini reviews in medicinal chemistry, 10(14), 1331-1344.

Jónsdóttir, S. Ó., Jørgensen, F. S., \& Brunak, S. (2005). Prediction methods and databases within chemoinformatics: emphasis on drugs and drug candidates. Bioinformatics, 21(10), 2145-2160. doi:10.1093/bioinformatics/bti314

Lahsasni, S., Ben Hadda, T., Masand, V., Pathan, N. B., Parvez, A., Warad, I., ... Aljofan, M. (2015). POM analyses of Raltegravir derivatives: a new reflection enlightening the mechanism of HIVintegrase inhibition. Research on Chemical Intermediates, 41(8), 5121-5136. doi:10.1007/s11164-014$1616-7$

Lima, L. M. (2007). Química Medicinal Moderna: desafios e contribuição brasileira. Química Nova, 30, 1456-1468.

Lozano, R., Naghavi, M., Foreman, K., Lim, S., Shibuya, K., Aboyans, V., ... Murray, C. J. L. (2012). Global and regional mortality from 235 causes of death for 20 age groups in 1990 and 2010: a systematic analysis for the Global Burden of Disease Study 2010. The Lancet, 380(9859), 2095-2128. $10.1016 /$ S0140-6736(12)61728-0

Miller, L. M., Keune, W.-J., Castagna, D., Young, L. C., Duffy, E. L., Potjewyd, F., ... Watson, A. J. B. (2017). Structure-Activity Relationships of Small Molecule Autotaxin Inhibitors with a Discrete Binding Mode. Journal of Medicinal Chemistry, 60(2), 722-748. doi:10.1021/acs.jmedchem.6b01597

Mombelli, E., Raitano, G., \& Benfenati, E. (2016). In Silico prediction of chemically induced mutagenicity: how to use qsar models and interpret their results. In Silico Methods for Predicting Drug Toxicity, 87-105.

Mustanski, B. S., Newcomb, M. E., Du Bois, S. N., Garcia, S. C., \& Grov, C. (2011). HIV in young men who have sex with men: a review of epidemiology, risk and protective factors, and interventions. The Journal of Sex Research, 48(2-3), 218-253. doi:10.1080/00224499.2011.558645

Neelakantan, H., Wang, H. Y., Vance, V., Hommel, J. D., McHardy, S. F., \& Watowich, S. J. (2017). Structure-activity relationship for small molecule inhibitors of Nicotinamide N-Methyltransferase. $J$ 
Med Chem, 60(12), 5015-5028. doi:10.1021/acs.jmedchem.7b00389

Nelson, K. A. Y. Y., \& Lehninger, A. L. (2002). Lehninger Princípios de bioquímica: Sarvier.

Novotny, T., Hendrickson, E., Soares, E. C. C., Sereno, A. B., \& Kiene, S. M. (2017). HIV/AIDS, tuberculose e tabagismo no Brasil: uma sindemia que exige intervenções integradas. Cadernos de Saúde Pública, 33.

Nunes, A. A., Caliani, L. S., Nunes, M. S., Silva, A. S. d., \& Mello, L. M. d. (2015). Análise do perfil de pacientes com HIV/Aids hospitalizados após introdução da terapia antirretroviral (HAART). Ciência \& Saúde Coletiva, 20, 3191-3198.

Oliveira, C. S. de, Lira, B. F., dos Santos Falcão-Silva, V., Siqueira-Junior, J. P., Barbosa-Filho, J. M., $\&$ de Athayde-Filho, P. F. (2012). Synthesis, Molecular Properties Prediction, and Anti-staphylococcal Activity of N-Acylhydrazones and New 1,3,4-Oxadiazole Derivatives. Molecules, 17(5). doi:10.3390/molecules17055095

Oliveira, de J. E. D., \& Marchini, J. S. (2008). Ciências nutricionais: aprendendo a aprender. Sarvier.

Oliveira, R. B. d., Zani, C. L., Ferreira, R. S., Leite, R. S., Alves, T. M. A., Silva, T. H. A. d., ... Romanha, A. J. (2008). Síntese, avaliação biológica e modelagem molecular de arilfuranos como inibidores da enzima tripanotiona redutase. Química Nova, 31, 261-267.

Peixoto, I. N., Souza, H. D. S., Lira, B. F., Silva, D. F., Lima, E. O., Barbosa-Filho, J. M., ... AthaydeFilho, P. F. d. (2016). Synthesis and Antifungal Activity Against Candida Strains of Mesoionic System Derived From 1,3-Thyazolium-5-thiolate. Journal of the Brazilian Chemical Society, 27, 1807-1813.

Pizzo, F., Lombardo, A., Manganaro, A., \& Benfenati, E. (2013). In silico models for predicting ready biodegradability under REACH: A comparative study. Science of The Total Environment, 463-464, 161-168. doi:https://doi.org/10.1016/j.scitotenv.2013.05.060

Price, N., \& Chaudhry, Q. (2014). Application of in silico modelling to estimate toxicity of migrating substances from food packaging. Food and Chemical Toxicology, 71, 136-141. doi:https://doi.org/10.1016/j.fct.2014.05.022

Ren, J., Esnouf, R., Hopkins, A., Ross, C., Jones, Y., Stammers, D., ... Stuart, D. (1995). The structure of HIV-1 reverse transcriptase complexed with 9-chloro-TIBO: lessons for inhibitor design. Structure, 3(9), 915-926.

Sanjuán, R., \& Bordería, A. V. (2010). Interplay between RNA structure and protein evolution in HIV1. Molecular biology and evolution, 28(4), 1333-1338.

Santos, W. M. d., Secoli, S. R., \& Padoin, S. M. d. M. (2016). Potential drug interactions in patients 
given antiretroviral therapy. Revista Latino-Americana de Enfermagem, 24.

Schaftenaar, G., \& de Vlieg, J. (2012). Quantum mechanical polar surface area. Journal of ComputerAided Molecular Design, 26(3), 311-318. doi:10.1007/s10822-012-9557-y

Silva, J. A. G., Dourado, I., Brito, A. M. d., \& Silva, C. A. L. d. (2015). Fatores associados à não adesão aos antirretrovirais em adultos com AIDS nos seis primeiros meses da terapia em Salvador, Bahia, Brasil. Cadernos de Saúde Pública, 31, 1188-1198.

Silva, M., Comin, M., Santos Duarte, T., Foglio, A. M., de Carvalho, E. J., do Carmo Vieira, M., ... Nazari Formagio, S. A. (2015). Synthesis, Antiproliferative Activity and Molecular Properties Predictions of Galloyl Derivatives. Molecules, 20(4). doi:10.3390/molecules20045360

Simonetti, E., Ethur, M. E., Castro, L. C., Kauffmann, C., Giacomin, A. C., Ledur, A., ... Freitas, E. M. (2016). Avaliação da atividade antimicrobiana de extratos de Eugenia anomala e Psidium salutare (Myrtaceae) frente à Escherichia coli e Listeria monocytogenes. Revista Brasileira de Plantas Medicinais, 18, 9-18.

Singh, H. P., Sharma, C. S., Mishra, S. S., Pandiya, H., \& Kumar, N. (2017). In silico ADME, Bioactivity and Toxicity Prediction of Some Selected Anti-Parkinson Agents. International Journal of Pharmaceutical and Phytopharmacological Research, 6(3), 64-67.

Singh, S., Gupta, A. K., \& Verma, A. (2013). Molecular properties and bioactivity score of aloe vera antioxidant compounds-in order to lead finding. Res J Pharm Biol Chem Sci, 4(2), 876-881.

Singh, U. P., \& Singh, R. K. (2011). Molecular docking analysis of novel non-nucleoside reverse transcriptase inhibitors in development: implication for rational drug design. Retrovirology, 8(2), P82. doi:10.1186/1742-4690-8-S2-P82

Siqueira, E. C. Obtenção de compostos intermediários para a síntese do agente anti-HIV Tenofovir, e de derivados do D-manitol. In: Universidade Federal Rural de Pernambuco.

Soares, F. A. (2011). Ensaios bioquímicos e celulares para a identificação de novos inibidores de TcGAPDH seletivos à HsGAPDH. (Doctoral dissertation, Universidade de São Carlos).

Souza, S. D. de. (2012). Estudo de inibidores de colinesterases aplicando técnicas de QSAR-2D (HQSAR) e docking molecular.

Veljkovic, V., Goeijenbier, M., Glisic, S., Veljkovic, N., Perovic, V. R., Sencanski, M., ... \& Paessler, S. (2015). In silico analysis suggests repurposing of ibuprofen for prevention and treatment of ebola virus disease. F1000Research, 4.

Veljkovic, V., Goeijenbier, M., Glisic, S., Veljkovic, N., Perovic, V. R., Sencanski, M., ... Paessler, S. 
Viegas Jr, C., Bolzani, V. d. S., \& Barreiro, E. J. (2006). Os produtos naturais e a química medicinal moderna. Química Nova, 29, 326-337.

WHO. (2018a). HIV/AIDS: key facts. Retrieved May 05, 2018, from http://www.who.int/en/newsroom/fact-sheets/detail/hiv-aids

WHO. (2018b). WHO statement and Q\&A on potential safety issue related with DTG. Retrieved May 05, 2018, from http://www.who.int/hiv/mediacentre/news/dtg-statement/en/ 